\title{
KETERTARIKAN SISWA PADA MATA PELAJARAN EKONOMI KELAS XI LINTAS MINAT EKONOMI DI SMA NEGERI 1 LAWANG TAHUN AJARAN 2016/2017
}

\author{
Wahyu Nila Megasari \\ Economic Education Program, Faculty of Economics, State University Malang \\ wahyumegasari@gmail.com
}

\begin{abstract}
This study aims to determine the causes of student interest in economic subjects on the class XI economy cross-interest in SMAN 1 Lawang and to determine whether the main factor in making students interested in economic subjects. The research method used is qualitative research with phenomenology approach. Data collection is done by interview and documentation. Judging from teacher or teacher factor is high. It can be seen from the interview that the students are very interested in the way the teacher teaches a nice, relaxed and not boring. Students' interest in the subjects of economics through teaching material factors is also high. This can be seen from the interviews that the teaching materials used are very clear and easy to understand. In terms of media, interest in terms of media used by teachers is high. It can be seen from the results of interviews that the media used by teachers in conveying materials because the teacher uses the media power point and sometimes also use the video in delivering the material. Judging from the factors of educational facilities is also very interesting. Students say that the facilities provided are very complete.
\end{abstract}

Keywords: Interest, Teachers, Teaching Materials, Learning Media, and Educational Facilities

History of Article:

Received:(11 July2017), Accepted : (19September 2017), Publised : (15Oktober 2017)

\section{Citation:}

Megasari, Wahyu Nila (2017) Ketertarikan Siswa Pada Mata Pelajaran Ekonomi Kelas Xi Lintas Minat Ekonomi Di Sma Negeri 1 Lawang Tahun Ajaran 2016/2017. [Student Interest In Economic Subjects of Class XI In SMA 1 Lawang 2016/2017]. Jurnal Pendidikan Ekonomi, 10(2), 130-136

(C) Universitas Negeri Malang 


\section{PENDAHULUAN}

Setiap orang yang melakukan sesuatu selalu didasari oleh rasa ketertarikan terhadap sesatu itu sendiri. Banyak faktor yang menimbulkan siswa tertarik pada suatu pelajaran diantaranya disebabkan oleh sesuatu yang ada dalam diri sendiri (internal) dan faktor yang berasal dari luar (eksternal). Menurut sugihartono (2007: p.76) faktor internal terdiri dari faktor jasmani dan faktor psikologis. Faktor jasmaniah meliputi faktor kesehatan dan cacat tubuh, sedangkan faktor psikologis meliputi integensi, keingintahuan, bakat, motivasi, kematangan, dan kelelahan. Faktor eksternal meliputi pengaruh dari oranglain atau lingkungannya misalnya dukungan keluarga, lingkungan sekolah dan lingkungan masayarakat.

Tingkah laku siswa ketika mengikuti proses pembelajaran mengindikasikan akan ketertarikan siswa tersebut terhadap pelajaran atau justru sebaliknya siswa tidak tertarik dengan pelajaran yang sedang berlangsung. Ketertarikan siswa ini merupakan salah satu tanda minat. Djamarah (2008: 191) mengatakan bahwa Minat adalah suatu rasa lebih suka dan rasa ketertarikan pada suatu hal atau aktivitas, tanpa ada yang menyuruh. Minat pada dasarnya adalah penerimaan akan sesuatu hubungan antara diri sendiri dengan sesuatu di luar diri (Slameto, 2010: p.180).

Banyak hal yang mempengaruhi ketertarikan siswa pada mata pelajaran ekonomi, di dalam penelitian ini penulis sebelumnya melakukan observasi awal mengenai faktor yang mempengaruhi ketertarikan siswa pada mata pelajaran ekonomi kelas XI LM dan selain itu penulis juga mengambil dari faktor eksternal yang mempengaruhi tumbuh kembangnyaketertarikan belajar siswa diantaranya disebabkan oleh faktor guru atau pengajar, faktor bahan ajar, faktor model pembelajaran yang digunakan, dan faktor fasilitas yang digunakan. Setiap siswa memiliki faktor ketertarikan yang berbeda-beda yang biasanya disebabkan oleh kondisi yang ada dalam diri siswa masing-masing. Hal itu nantinya akan menentukan siswa dalam memberikan alasan ketertarikannya terhadap mata pelajaran ekonomi. Hal ini sesuai dengan hasil penelitian Puji Wahyuni, Yola Malinda \& Syailendra Eka Saputra (2017) yang menyatakan bahwa terdapat banyak faktor yang mempengaruhi minat belajar siswa pada mata pelajaran ekonomi kelas X SMA Negeri 1 Kecamatan Pancung Soal Kabupaten Pesisir Selatan, antara lain Motivasi belajar, Metode pembelajaran, Media pembelajaran, dan Lingkungan sekolah. Faktor-faktor tersebut berpengaruh secara signifikan terhadap minat belajar siswa kelas X SMA Negeri 1 Pancung Soal

Ilmu ekonomi merupakan salah satu percabangan dari ilmu pengetahuan sosial, yang mana ekonomi ilmu ekonomi itu merupakan disiplin ilmu yang berhubungan dengan individu dan masyarakat dalam membuat suatu pilihan dengan atau tanpa uang, dengan menggunakan sumber daya yang terbatas namun dapat digunakan dengan berbagai cara untuk menghasilkan suatu barang untuk dapat dikonsumsi. Dari pengertian tersebut jelas bahwa ekonomi sangat erat hubungannya dengan kehidupan sehari-hari.

\section{METODE PENELITIAN}

Penelitian ini menggunkan pendekatan deskriptifkualitatif. Pendekatan kualitatif diharapkan mampu menghasilkan uraian yang mendalam tentang ucapan, tulisan, dan atau perilaku yang dapat diamati dari suatu individu, kelompok, masyarakat. 
Penelitian deskriptif kualitatif ini bertujuan untuk mendeskripsika apa yang saatini berlaku. Di dalam mencatat, analisis dan menginterpretasikan kondisi yang sekarang ini terjadi atauada. Dengan kata lain penelitian deskriptif kualitatif xinibertujuanuntukmemperolehinformasi-informasimengenaikeadaan yang ada.

Jenis yang digunakan dalam penelitian ini adalah fenomenologi karena penelitian ini berdasarkan dengan keadaan yang sebenarnya. Penelitian tentang analisis ketertarikan siswa pada mata pelajaran ekonomi kelas XI LM ini, akan dilakukan di SMA Negeri 1 Lawang tahun ajaran 2016/2017 dengan waktu yang dibatasi selama 3 bulan. Penelitian tentang ketertarikan siswa pada mata pelajaran ekonomi ini dilakukan di SMA Negeri 1 Lawang yang beralamatkan di jalan Pramuka No.152 Lawang Kabupaten Malang.

Sumber data dalam penelitian ini diperoleh dari hasil observasi, hasil wawancara, dan analisis dokumen. Dalam penelitian ini data diolah, dianalisis, dan diperoleh dengan cara melakukan observasi yang dilakukan dikelas saat pembelajaran berlangsung. Selain itu juga dilakukan wawancara kepada siswa kelas XI LM. Jumlah siswa yang akan diwawancara ada 10 siswa dari XI LM dan cara pengambilan sampel menggunakan teknik Snowball Sampling yaitu penentuan sampel yang mula-mula pengambilan sampel utama dengan beberapa kreteria yang telah ditentukan oleh penulis, yaitu keaktivan masuk kelas, bertanya dan menjawab saat pelajaran berlangsung serta nilai yang sama dengan atau di atas KKM sebesar 75 .

tahapan-tahapan analisis data dalam penelitian ini sesuai dengan analisis data kualitatif yaitu sebagai berikut: 1) pengumpulan data 2) reduksi data 3) penyajian data 4) penarikan kesimpulan atau verfikasi.

Dalam penelitian ini, penulis menggunakan teknik triangulasi dalam menguji keabsahan data. Triangulasi dalam penelitian ini adalah triangulasi sumber. Triangulasi sumber dilakukan karena dalam penelitan ini menggunakan teknik wawancara dalam mengumpulkan data. Sumberdata diperoleh dari 10 siswa kelas XI Lintas Minat dan 1 guru mata pelajaran ekonomi kelas XI Lintas Minat SMA Negeri 1 Lawang Kabupaten Malang.

\section{HASIL DAN PEMBAHASAN}

Observasi kelas dilakukan saat proses pembelajaran ekonomi berlangsung. Hal ini di lakukan agar mendapat informasi yang sesuai dengan kenyataan di lapangan. Observasi ini dilakukan langsung pada saat pembelajaran di kelas untuk mengetahui sikap yang dilakukan oleh peserta didik. Selain itu juga untuk mengetahui ciri-ciri siswa yang mengalami ketertarikan untuk belajar ekonomi dikelas tersebut. Hal ini dilakukan sebagai pedoman untuk menentukan informan yang sesuai yaitu siswa yang tertarik dengan pelajaran ekonomi.

Hasil observasi kelas ternyata banyak ditemukan siswa yang tertarik dengan pelajaran ekonomi sehingga membantu observer lebih mudah memilih informan yang sesuai dengan kriteria yang ditentukan oleh penulis. Dari hasil observasi awal penulis mengambil 10 siswa untuk dijadikan informan, selain itu penulis ingin menggali faktor apa saja yang membuat mereka tertarik dengan pelajaran ekonomi.

Mata pelajaran ekonomi merupakan bagian dari ilmu sosial yang mempelajari bagaimana cara agar manusia dapat memenuhi kebutuhan akan hidupnya. Mata pelajaran ekonomi sekarang bukan hanya mata pelajaran hafalan melainkan juga ada rumus-rumus perhitungannya, itulah salah satu faktor yang menjadikan siswa 
lintas minat tertarik dengan pelajaran ekonomi. Ketertarikan pada suatu pembelajaran bukan hanya dimiliki oleh siswa yang memiliki IQ tinggi melainkan ketertarikan juga bisa dimikili oleh setiap siswa dengan berbagai faktor yang mempengaruhinya. Dari wawancara yang dilakukan oleh penulis sebagian besar ketertarikan berasal dari guru dan bahan ajar. Hal ini dapat dilihat dari hasil wawancara yang dilakukan oleh penulis kepada 10 informannya di SMAN 1 Lawang.

Pada umumnya ketertarikan pada setiap siswa berbeda-beda, ada siswa yang sangat tertarik, kurang tertarik dan tidak tertarik. Berdasarkan hasil wawancara yang penulis lakukan di kelas XI Lintas Minat, penulis menemukan bahwa siswa kelas XI Lintas Minat sangat tertarik dengan pelajaran ekonomi, karena berbagai faktor.

Dari beberapa informan terlihat bahwa mereka tergolong siswa yang memiliki tingkat keteratikan pada mata pelajaran ekonomi yang tinggi, hal tersebut dapat dilihat dari nilai ulangan harian serta daftar hadir sebagi salah satu bukti bahwa mereka sangat tertarik dengan pelajaran ekonom Informan tersebut tergolong sangat aktif dalam pembelajaran menjawab pertanyaan yang diberikan oleh guru. Berdasarkan hasil wawancara, informan tertarik dengan mata pelajaran ekonomi dapat dilihat dari berbagai factor yaitu ada yang tertarik dengan cara guru menagajar, ada juga yang tertarik dengan media yang digunakan oleh guru, ada pula yang tertarik dengan bahan ajar, dan juga fasilitas yang disediakan oleh sekolah.

Di kelas XI lintas minat ekonomi di SMAN 1 Lawang penulis juga menemukan bahwa terdapat persaingan yang terjadi di kelas tersebut. Mereka berusaha untuk mendapatkan nilai yang bagus dengan cara beradu argument serta menjawab pertanyaa-pertanyaan yang diberikan oleh guru. Hal tersebut dapat dilihat dari hasil wawancara yang penulis lakukan dengan guru mata pelajaran ekonomi.

Selain itu penulis juga menemukan bahwa selain faktor-faktor yang mendorong informan agar tertarik juga mata pelajaran ekonomi juga ada faktor lain yaitu dengan beranggapan bahwa mata pelajaran ekonomi sangat dibutuhkan dimasa yang akan datang. Hal tersebut terlihat disetiap hasil wawancara informan.

\section{Pembahasan}

Tingkat ketertarikan siswa mata pelajaran ekonomi di kelas XI lintas minat yang dimiliki masing-masing siswa berbeda. Hal itu dapat dilihat dari sikap siswa saat kegiatan belajar mengajar di dalam kelas. Hal tersebut juga dapat dilihat dari analisis yang menunjukan bahwa siswa kelas XI LM memiliki tingkat ketertarikan yang kuat terhadap mata pelajaran ekonomi, itu yang membuat siswa sangat semangat dalam menerima pelajaran ekonomi.

Minat juga dapat memicu timbulnya ketertarikan dalam diri siswa. Minat belajar yang dimiliki oleh siswa dapat ditentukan oleh kondisi yang terdapat di dalam kelas ketika proses pembelajaran dilakukan, sehingga kondisi kelas yang kondusif memberikan dukungan untuk menciptakan minat siswa dalam mengikuti proses pembelajaran. Menurut Slameto (2010: p. 180) "suatu minat dapat diekspresikan melalui suatu pernyataan yang menunjukan siswa lebih menyukai suatu hal dari pada lainnya, dapat pula dimanisfestasikan melalui partisipasi dalam suatu aktivitas." Partisipasi aktif ini terlihat dari hasil wawancara pada sebagian besar subjek yang menyatakan bahwa informan terlibat dalam kegiatan belajar mengajar ekonomi. Keterlibatan tersebut dapat ditunjukan ketika pelajaran ekonomi 
berlangsung, misalnya berani menjawab pertanyaan dari guru, berani bertanya kepada guru dan temanya.

Hal positif yang diperoleh dari besarnya minat (ketertarikan) siswa mata pelajaran ekonomi di kelas XI lintas minat seperti yang dijelaskan di atas misalnya berani menjawab pertanyaan dari guru, berani bertanya kepada guru dan temanya, dll tentunya akan memberikan dampak positif juga dalam prestasi belajar siswa. Sebagaimana yang dijelaskan oleh Rusmiati (2017) dalam jurnal Pendidikan dan Ekonomi Volume 1, No. 1, Februari 2017: Page 21-36, bahwa minat belajar pelajaran ekonomi mempunyai pengaruh terhadap prestasi belajar bidang studi ekonomi siswa Madrasah Aliyah Al Fattah Sumbermulyo.

Ketertarikan juga dapat dilihat ketika siswa fokus dengan pelajaran yang disampaikan oleh guru. Dengan demikian dapat disimpulkan bahwa siswa kelas XI LM ekonomi sangat tertarik dengan mata pelajaran ekonomi.

Menurut Slameto (2010: p.180) menyatakan bahwa "siswa yang memiliki minat dalam suatu subjek tertentu cenderung memberikan perhatian terhadap subjek tersebut." Apabila siswa memiliki minat dalam mata pelajaran ekonomi maka dia akan memperhatikan secara seksama saat guru menjelaskan materi pelajaran tersebut.

Dari paparan data dan temuan penelitian dalam penelitian ini, maka dapat diketahui bahwa ketertarikan siswa kelas XI LM tertarik pada mata pelajaran ekonomi disebabkan oleh bebera factor yaitu sebagai berikut:

\section{Faktor guru}

Dalam proses pembelajaran guru memiliki peran untuk menyampaikan materi serta member fasilitas belajar bagi siswa untuk mencapai tujuan. Dalam wawancara yang penulis lakukan dapat diketahui bahwa metode mengajar yang digunakan guru adalah metode ceramah dan jarang menggunakan metode presentasi tiap kelompok. Metode yang digunakan oleh guru yaitu metode ceramah lebih dapat menarik perhatian dan mengurangi rasa bosan yang ada dalam diri siswa sehingga guru lebih sering menggunakan metode yang bervariasi lainnya. Hal ini dapat dilihat dari hasil wawancara. Dengan demikian dapat disimpulkan bahwa siswa kelas XI LM lebih tertarik dengan cara mengajar guru yang menggunakan metode ceramah kareca cara yang disampaikan guru saat belajar tidak monoton dan banyak diselingi oleh candatawa.

\section{Faktor media pembelajaran}

Media merupakan perantara penyampaian materi. Di SMA N 1 Lawang media yang digunakan pada mata pelajaran ekonomi adalah papan tulis dan LCD. Dalam hasil wawancara dapat dilihat tentang penggunaan papan tulis dan LCD yang sudah maksimal serta buku pegangan siswa dimana setiap siswa memliki buku pegangan masing-masing. Dengan menggunakan media pembelajaran siswa akan lebih tertarik dengan suatu pelajaran tersebut sehingga perlu menggunakan media dalam penyampain materi. Penggunaan media bukan hanya digunakan oleh guru saja melainkan dapat digunakan siswa untuk menyampaikan pendapatnya melalui presentasi kelompok. Hal ini sesuai dengan yang dikemukaan oleh Sadiman dkk (2010: p.10) yang menyatakan bahwa "Sebagai pembawa pesan, media tidak hanya digunakan oleh guru tetapi yang lebih penting lagi dapat digunakan oleh siswa." 


\section{Faktor bahan ajar}

Minat besar pengaruhnya terhadap belajar, karena bila bahan pelajaran yang dipelajari tidak sesuai dengan minat siswa, siswa tidak akan belajar dengan sebaikbaiknya, karena tidak ada perasaan tertarik yang ada dalam dirinya. Bahan ajar yang menarik minat siswa lebih mudah dipelajari karena siswa sudah tertarik dengan bahanm ajarnya. Bahan ajar yang digunakan siswa kelas XI LM adalah LKS dimana pembahasan yang ada didalamnya cenderung ringkas dan bahasanya mudah dimengerti sehingga siswa lebih tertarik untuk belajar pelajaran ekonomi. Hal tersebut sesuai dengan yang dikemukakan oleh Dimyati \& Mudjiono (2009: p.33) yang menyatakan bahwa "bahan belajar dapat dijadikan sarana mempergiat belajar, serta dapat menarik perhatian siswa."

\section{Faktor Fasilitas pembelajaran}

Fasilitas pembelajaran merupakan salah satu faktor penunjang dalam keberhasilan belajar di sekolah juga merupakan salah satu faktor yang mempengaruhi ketertarikan siswa dalam belajar ekonomi. Hal tersebut dapat dilihat dari hasil wawancara yang yang dapat disimpulkan bahwa dengan adanya fasilitas uyang disediakan sekolah akan mempermudah siswa dalam melakukan ataupun mencari materi yang belum dimengerti. Fasilitas pembelajaran yang disediakan oleh sekolah adalah perpustakaan, dimana perpustakaan sudah tersedia buku paket ekonomi untuk menunjang proses pembelajaran, ruang kelas yang memadahi sehingga siswa lebih nyaman. Fasilitas belajar yang dimaksud penulis adalah sarana prasarana. Hal tersebut sesuai dengan yang dikemukan oleh Mulyasa (2003: p.49) yang menyatahkan bahwa "sarana pendidikan adalah peralatan dan perlengkapan yang secara langsung dipergunakan dan menunjang proses pembelajaran.

\section{KESIMPULAN}

Berdasarkan deskripsi hasil pene-litian dan pembahasan mengenai ketertarikan siswa XI lintas minat pada mata pelajaran ekonomi di SMA N 1 Lawang dapat diambil kesimpulan sebagai berikut: 1) Faktor guru sangat berpengaruh terhadap ketertarikan siswa pada mata pelajaran ekonomi kelas XI Lintas Minat di SMAN 1 Lawang disebabkan karena cara mengajar guru yang efisien dan tidak membosankan; 2) Faktor bahan ajar juga sangat mempengaruhi ketertarikan siswa pada mata pelajaran ekonomi kelas XI Lintas Minat di SMAN 1 Lawang disebabkan karena bahan ajar yang digunakan sangat banyak seperti LKS dan buku paket; 3) Faktor media pembelajaran juga mempengaruhi ketertarikan siswa pada mata pelajaran ekonomi kelas XI Linatas Minat di SMAN 1 Lawang disebabkan karena media yang digunakan saat proses pembelajaran sangat mendukung siswa untuk lebih memahami materi yang diberikan. Seperti media cetak dan media elektonik; 4) Faktor fasilitas belajar juga mempengaruhi ketertarikan siswa pada mata pelajaran ekonomi kelas XI Lintas Minat di SMAN 1 Lawang disebabkan oleh lengkapnya fasilitas yang disediakan oleh sekolah khususnya pada saat mata pelajaran ekonomi berlangsung.

Berdasarkan kesimpulan yang telah dijelaskan, maka saran yang dapat diajukan adalah sebagi berikut: 1) Bagi guru: Dengan penelitian ini guru diharapkan selalu menumbuhkan rasa ketertarikan kepada mata pelajaran ekonomi agar hasil yang dicapai siswa dapat terus meningkat; 2) Bagi sekolah: Bagi sekolah saran 
penulis adalah meningkatkan fasilitas dalam mendukung pembelajaran dan member kegiatan ekstra kurikuler yang berkaitan dengan pembelajaran; 3) Bagi peneliti lain: Bagi peneliti lain diharapkan penelitan ini bisa menjadi referensi serta dapat melanjutkan penelitian mengenai ketertarikan siswa pada mata pelajaran ekonomi dengan subjek yang lebih beragam serta lebih lengkap.

\section{DAFTAR RUJUKAN}

Dimyati dan Mudjiono (2009) Belajar dan Pembelajaran. Jakarta: RinekaCipta Djamarah, S. B. (2008). Psikologi Belajar. Jakarta: Rineka Cipta

Mulyasa, E. (2007).Menjadi Guru Profesional menciptakan Pembelajaran Kreatif dan Menyenangkan. Bandung: PT. RemajaRosdakaryaArief S, Sadiman, dkk (2010) Media Pendidikan. Jakarta: Raja Grapindo Persada.

Rusmiati. (2017). Pengaruh minat belajar terhadap prestasi belajar bidang studi ekonomi siswa MA Al fattah Sumbermulyo. UTILITY: Jurnal Ilmiah Pendidikan dan Ekonomi, 1(1), 21-36.

Slameto.(2010) .Belajar dan Faktor-Faktor yang Mempengaruhinya. Jakarta: PT Rineka Cipta

Sugihartono, dkk.(2007) PsikologiPendidikan. Yogyakarta: UNY Press Syah, Muhibbin. (2010) PsikologiPendidikan. Bandung: PT. Remaja Rosdakarya Wahyuni, Puji \& YolaMalinda, \& Syailendra Eka Saputra (2017) Faktor-Faktor Yang Mempengaruhi Minat Belajar Siswa Pada Mata Pelajaran Ekonomi Kelas X SMA Negeri 1 Kecamatan Pancung Soal Kabupaten Pesisir Selatan. Jurnal Ilmiah Mahasiswa STKIP PGRI Sumbar, (online), http://jim.stkip-pgrisumbar.ac.id/jurnal/download/5135 